\title{
CONFESSOR, TRAITOR OR PROSECUTOR: ON THE RITUALIZED RELATIONSHIPS BETWEEN KINGS AND BISHOPS THROUGH THE PRISM OF OTTONIAN HISTORIOGRAPHY
}

\author{
ILIANA KANDZHA \\ Central European University, Department of Medieval Studies \\ E-mail: kandzha_iliana@phd.ceu.edu
}

\begin{abstract}
This paper is devoted to the analysis of the episcopal behavior and the interpretive frameworks that writers of the Ottonian age used to describe their actions. The focus of the research are various narrative representations, which were attached to the relationships between bishops and kings in the medieval historiography. The saintly bishop, the spiritual instructor of a king, the prosecutor of a ruler, and the bishop-traitor were the most prominent literary models, or modes of description, used in texts from the tenth and eleventh centuries. These modes of episcopal representations, in their relation to royal power, are perceived as parts of the coherent narrative strategies utilized by the medieval historiographers to meet their own aims. These aims included increasing the prestige of a community represented by a bishop, criticizing royal policies, condemning political rivals or justifying their own position. It is argued that all these various literary roles, thrusted upon bishops by chroniclers, hagiographers or polemicists, were realizations of the milestone concepts of episcopal power and medieval political theology: admonition and familiarity. These literary roles thus allowed Ottonian writers to imagine a bishop as being an intimate friend, a loyal lord, a prophet and a pastor to the ruling king and his realm.

Keywords: bishop; narrative representation; Imperial Church; Holy Roman Empire; 11th Century
\end{abstract}

The image of a saintly bishop is one of the most remarkable literary representations that a bishop could acquire in the Ottonian kingdom. Ascribing the status of a saint to an individual bishop required that his depiction in literary and liturgical texts had a specific character, beyond the confines of the bishop's actual biography ${ }^{1}$. This stylization was not required exclusively by conventions of a hagiographic genre. A newly created image, imposed on a bishop, was a product of its political and cultural milieu and often addressed the interests of the impresario of a bishop's cult, a religious community or a royal

1 For Ottonian (episcopal) sanctity see: Patrick CORBET, Les saints ottoniens: Sainteté dynastique, royale et féminine autour de l'an Mil. Sigmaringen 1986; Walter BERSCHIN, Biographie und Epochenstil im lateinischen Mittelalter: ottonische Biographie, das hohe Mittelalter 920-1220, vol. 4. Stuttgart 1999, pp. 59-218; Eric PALAZZO, L’évêque et son image: l'illustration du pontifical au Moyen Age. Turnhout 2000. On the types of sanctity see: Michael GOODICH, Vita Perfecta, the Ideal of Sainthood in the Thirteenth Century. Stuttgart 1982; Andre VAUCHEZ, Sainthood in the Later Middle Ages. Cambridge 1997. 
court. In addition, a specific stylization of relations between the saintly bishop and the worldly power was required. For example, the bishop would be expected to join the king in spreading the Christian faith by carrying out missionary activities or taking to arms against pagans, as was the case for St Ulrich of Augsburg or St Bruno of Cologne. I believe the figure of a saintly bishop is a revealing example, showing how personal relations between individuals, or formal ties between two offices, could become the subject of literary transformation. Since the ideal of the saintly bishop and its use in Ottonian political discourse has been widely discussed in studies of Ottonian hagiography, I will not elaborate more on this specific stylization ${ }^{2}$. However, other literary representations of bishops have received relatively little attention, especially as parts of coherent narrative strategies. Therefore, I turn to these in the present paper.

An initial ideal of a holder of an episcopal office is expressed as following: he "must be above reproach, the husband of one wife, sober-minded, self-controlled, respectable, hospitable, able to teach, not a drunkard, not violent but gentle, not quarrelsome, not a lover of money"3. However, political and social circumstances demanded from an Ottonian bishop to be much more than an embodiment of Christian virtues and a good manager "of his own household".

In traditional historiography, the position of the bishop in the Ottonian realm and their relations with royal power are predominantly viewed within the framework of the Reichskirchensystem ${ }^{4}$. However, Ottonian kings and bishops were engaged in a much more intricate set of "checks and balances". Their interactions depended not only on the ecclesiastical system of the realm, but also on Christian traditions of relations between kings and clerics, canon law, momentary political needs, and personal impulses. Together, these notions make possible a diverse palette of personal and official ties between secular rulers and clerics. In the vacuum of bureaucratic organization or stable mechanisms of royal and episcopal elections, bishops needed to be "charismatic figures" and effective actors, able to intervene into politics, gain public attention and support, and promote their interests 5 .

2 For example, see: Stephanie HAARLÄNDER, Vitae episcoporum: eine Quellengattung zwischen Hagiographie und Historiographie, untersucht an Lebensbeschreibungen von Bischöfen des Regnum Teutonicum im Zeitalter der Ottonen und Salier. Stuttgart 2000; Thomas WÜNSCH, Der heilige Bischof - Zur politischen Dimension von Heiligkeit im Mittelalter und ihrem Wandel, in: Archiv für Kulturgeschichte 82 (2000), pp. 261-302; David A. WARNER, Saints, Pagans, War and Rulership in Ottonian Germany, in: Robert C. Figueira (ed.), Plentitude of Power: the Doctrines and Exercise of Authority in the Middle Ages: Essays in Memory of Robert Louis Benson. Aldershot 2006, pp. 11-35; Andreas HAMMER, Interferences Between Hagiography and Historiography: Bishop Ulrich of Augsburg and Emperor Henry II, in: Amsterdamer Beiträge Zur Älteren Germanistik 70 (2013), pp. 179-194.

31 Timothy 3:1-7; See: John Stephens OTT - Anna TRUMBORE JONES, Introduction: the Bishop Reformed, in: The Bishop Reformed: Studies of Episcopal Power and Culture in the Central Middle Ages. Aldershot 2007, pp. 1-20.

4 For example, see: Herbert ZIELINSKI, Der Reichsepiskopat in spätottonischer und salischer Zeit, 10021125. Wiesbaden 1984; Albrecht Graf FINCK von FINCKENSTEIN, Bischof und Reich: Untersuchungen zum Integrationsprozess des ottonisch-frühsalischen Reiches (919-1056). Sigmaringen 1990. For the recent approach towards this framework see: Timothy REUTER, The 'imperial Church System' of the Ottonian and Salian Rulers: a Reconsideration, in: The Journal of Ecclesiastical History 33 (1982), pp. 347-374.

5 Timothy REUTER, Ein Europa der Bischöfe: das Zeitalter Burchards von Worms, in: Wilfried Hartmann (ed.), Bischof Burchard von Worms: 1000-1025. Mainz 2000, pp. 1-28. 
However, approaching this variety of king-bishop relations, we face impediments caused by Ottonian historiography ${ }^{6}$. A number of factors turn influential political actors into mere literary figures. These include the personal motives of tenth-eleventh century authors and the expectations of their audiences, literary traditions and topoi ${ }^{7}$. Chroniclers of the Ottonian Age turned the political protagonists of the period into tools for personal or communal self-fashioning, for creating useful pasts, for criticizing or getting rid of enemies, for propagating political or ecclesiastical ideas, and for exercising rhetoric.

In this paper, I analyse several specific "roles", or literary representations, which were attached to bishops by Ottonian writers; in other words - episcopal behaviour and interpretive frameworks that contemporaries used to understand their actions. I also pay attention to literary means used to construct those images and to reasons for creating these representations. I believe that this approach makes it possible to explain, or at least rethink, some of the "famous episodes" emerging from the convoluted relations between kings and bishops as we know them from the chronicles, gesta or saintly lives. Moreover, I acknowledge that the relations between kings and bishops, as seen in different literary forms, had a strong political and social background. However, as far as we are dealing with literary forms, it is useful to consider literary traditions of imagining and describing mundane rulers and clerics in concert with the aims and social logic of the text itself.

In the present study, I am mostly concerned with those relations between bishops and kings which are based on notions of familiaritas and auctoritas ${ }^{8}$. Signs of friendship, benevolence, closeness, enmity and power were expressed and negotiated through rituals, often referred to as Spielregeln ${ }^{9}$. Friendship and authority, combined with the idea of episcopal admonition, value of proximity, the virtue of pastoral care, and their represen-

6 By an umbrella-term of Ottonian historiography I understand a group of historical and hagiographic texts created in the tenth and eleventh centuries in the German kingdom under the rule of the members of the Liudolfing family; Martina GIESE, Die Historiographie im Umfeld des ottonischen Hofes, in: Rudolf Schieffer - Jarosław Wenta - Martina Giese (eds.), Die Hofgeschichtsschreibung im mittelalterlichen Europa: Projekte und Forschungsprobleme. Toruń 2006, pp. 19-37.

7 Gabrielle M. SPIEGEL, The Past as Text: the Theory and Practice of Medieval Historiography. Baltimore 1997; Hans-Werner GOETZ, Geschichtsschreibung und Geschichtsbewusstsein im hohen Mittelalter. Berlin 1999; Gerd ALTHOFF, Was verstehen Mittelalter-Historiker eigentlich unter einer Fiktion?, in: Merle Marie Schütte - Kristine Rzehak - Daniel Lizius (eds.), Zwischen Fakten und Fiktionen: Literatur und Geschichtsschreibung in der Vormoderne. Würzburg 2014, pp. 155-168.

8 Gerd ALTHOFF, Verwandte, Freunde und Getreue: zum politischen Stellenwert der Gruppenbindungen im frühen Mittelalter. Darmstadt 1990; Geoffrey KOZIOL, Begging Pardon and Favor: Ritual and Political Order in Early Medieval France. Ithaca/London 1992; Sean J. GILSDORF, The Favor of Friends: Intercession and Aristocratic Politics in Carolingian and Ottonian Europe. Leiden 2014.

9 Gerd ALTHOFF, Spielregeln der Politik im Mittelalter: Kommunikation in Frieden und Fehde. Darmstadt 1997. This theory, though remaining one of the most significant in the field of ritual studies, faced a lot of criticism, e.g.: Philippe BUC, Noch einmal 918-919: Of the Ritualized Demise of Kings and of Political Rituals in General, in: Gerd Althoff (ed.), Zeichen - Rituale - Werte: Internationales Kolloquium Des Sonderforschungsbereichs 496 an Der Wesfälischen Wilhelms-Universität Münster. Münster 2004, pp. 151-178; Hanna VOLLRATH, Haben Rituale Macht?: Anmerkungen zu dem Buch von Gerd Althoff: 'Die Macht der Rituale, Symbolik und Herrschaft im Mittelalter', in: Historische Zeitschrift 284 (2007), pp. 385-400; Peter DINZELBACHER, Warum weint der König?: eine Kritik des mediävistischen Panritualismus. Badenweiler 2009. Moreover, this approach, when applied to studying the biography of a ruler, has led to "pan-ritualisation" of history, as has been argued by Borgolte: Michael BORGOLTE, Biographie ohne Subjekt, oder wie man durch quellenfixierte Arbeit Opfer des Zeitgeistes werden kann, in: Göttingische Gelehrte Anzeigen 249 (1997), pp. 128-141. 
tations by medieval authors, will be core points of reference for the current study. These aspects provide the following literary models of behaviour for the bishop:

1. Firstly, a personal confessor to the king;

2. Secondly, a prosecutor of the king's unfavourable policies, who has the authority to beseech the ruler or even impose penance on the king;

3. Thirdly, a traitor, who fails to honour his pledge to the king and thus disregards his pastoral duties.

In the following, I deal with each of these literary types at length before synthesizing them in my conclusion.

\section{Bishop-confessor}

On the first pages of the Life of Burchard of Worms, written soon after the death of Bishop Burchard in 1025, the following passage concerning the relations between Emperor Otto III and Bishop Franko, Burchard's brother and predecessor on the episcopal see, can be found ${ }^{10}$ :

"With a vigilant spirit, [Franko] was zealous in the service of the emperor for more than one year and was often a party to his secrets. Whenever something regarding more important matters was to be discussed, the emperor treated him with such great familiarity and authority (even though he was an adolescent) that anything was only rarely decided without his counsel" 11 .

This short episode presents the closest and most intimate relations between Otto and Franko: the emperor entrusts Franko with his secrets and seeks his council when deciding on political affairs.

The following scene describes how Otto and Franko went to Italy in 999 and practiced repentance together, "having put on hair shirts and with completely bare feet" 12 . This episode is a culmination of the amicitia motif. It is a high privilege, indeed, to repent together with the emperor and to share one of the sacraments with him. This voluntary practice of repentance brings the odour of sanctity to both the bishop and the emperor through "visions and divine conversations"13.

Even though Bishop Franko is not the main protagonist of the Vita, setting up this image of familiaritas and amicitia between Franko and the Holy Roman Emperor is vital:

10 For more details about Burchard see a recent volume: Wilfried HARTMANN, Bischof Burchard von Worms: 1000-1025. Mainz 2000.

11 Vita Burchardi episcopi, ed. Georg WAITZ, in: MGH Scriptores (in Folio). Bd. 4. Hannover 1841, p. 833 (Ibique plus quam unius anni spacio in servitio imperatoris vigilanti animo studebat, eiusque secretis saepe intererat, et quando de rebus maioribus tractandum aliquid erat, tanta familliaritate et auctoritate, quamvis iuvenis esset, apud imperatorem habebatur, ut sine ipsius consilio raro aliquid statueretur); The Life of Bishop Burchard of Worms, trans. W. L. North, in: Medieval Sourcebook, https:// legacy.fordham.edu/Halsall/source/1025burchard-vita.asp.

12 Vita Burchardi episcopi, p. 833 (Eodem tempore imperator et praedictus episcopus, induti ciliciis, pedibus penitus denudatis, quandam speluncam iuxta sancti Clementis ecclesiam clam cunctis intraverunt, ibique in orationibus et ieiuniis necnon in vigiliis quauotdecim dies latuerunt.).

13 Vita Burchardi episcopi, pp. 833-834 (Ferunt quidam, visionis et allocutionibus divinis eos crebro hoc loco fuisse consolatos); The Life of Bishop Burchard of Worms (as above). 
not only are the two personalities connected, but the two offices as well ${ }^{14}$. The same type of relations is outlined between the office of the German king and the bishop of Worms with regards to Burchard, the main character of the Vita. Burchard supported Duke Henry of Bavaria, future Henry II, during the contest for the German throne in 1002 and helped to stifle the rebellion of the Carinthian dukes. Even more intimate ties connected Burchard to Conrad II, Henry's successor. While Conrad was young,

"The man of God [Burchard of Worms] summoned the boy [Conrad] and taught him the fear as well as the love of God and raised him as if he was an adopted son. And because he perceived in him a stability of spirit, he loved him more than the rest. It was he that God later elevated through His clemency to the throne of the kingdom"15.

For the author, it was important to underline the continuity of a close relationship between the German kings and the bishops of Worms, between the individuals as well as the offices. Why was it possible to entrust a bishop with the role of a king's councillor, confessor, and spiritual teacher, even when he, as a cleric, was subordinate to the ruler?

The answer lies in the concept of admonitio: the episcopal duty to "care about salvation and admonish brethren and kings"16. The responsibility of advising a ruler was thrusted onto the bishop already in Gregory I's Regula Pastoralis, hence the bishop was entrusted with the ruler's personal salvation and thus the salvation of the whole realm ${ }^{17}$. It was a sacral moral duty of a bishop to offer a council to a king, a friend and his flock. Otherwise, a bishop falls into a sin of negligentia and fails to conduct his pastoral office ${ }^{18}$. This idea of "monition and advice", a widely utilized discourse among kings and prelates in the Carolingian kingdom, enabled Ottonian authors to present the relations between the emperor and the bishop as based on council and authority ${ }^{19}$. In recent studies, the idea of episcopal admonition is considered to be "central to the self-representation of prelates across the high medieval west, and that it was more deeply engrained and more widely practiced than modern scholars have often recognized" 20 .

The author of the Life of Burchard was not alone in his attempt to present his protagonist as having the most intimate relations with the king. Several means were used to

14 Briefly on the development of tight connections between a ruler and episcopate mostly through the royal chapel see: GILSDORF (as above), pp. 126-128.

15 Vita Burchardi episcopi, p. 835 (Hunc vir Dei venerabilis ad se vocatum, Dei timorem pariter et amorem docuit et quasi adoptivum nutrivit. Et Quia stabilitatem animi in eo intellexit, prae ceteris multum illum dilexit. Quem Deus postea in solium regni clementer exaltavit.); The Life of Bishop Burchard of Worms (as above).

16 Monika SUCHAN, Monition and Advice as Elements of Politics, in: Ludger Körntgen - Dominik Wassenhoven (ed.), Patterns of Episcopal Power: Bishops in Tenth and Eleventh Century Western Europe. Berlin 2011, p. 45; Björn WEILER, Clerical Admonitio, Letters of Advice to Kings and Episcopal Self-Fashioning, c. 1000 - c. 1200, in: History 102, no. 352 (2017), pp. 557-575.

17 GREGORY the Great, The Book of Pastoral Rule. Crestwood/New York 2007, esp. pp. 93-97.

18 Mayke de JONG, The Penitential State: Authority and Atonement in the Age of Louis the Pious, 814-840. Cambridge/New York 2009, p. 113.

19 The Admonitio generalis introduced by Charlemagne in 789 was designed, on the one hand, to reinforce the ruler's responsibility for the salvation of his kingdom, comparing him to the new King Josiah. On the other hand, the capitulary highlighted the importance of clerical guidance and council for the realm. Admonitio generalis, as a part of Charlemagne's political and legislative reforms, was largely distributed throughout the empire and later found reception in the Ottonian kingdom. See JONG (as above), esp. pp. 116-118; Monika SUCHAN, Mahnen und Regieren: die Metapher des Hirten im früheren Mittelalter. Berlin 2015, pp. 233-270.

20 WEILER (as above), p. 557. 
present the bishop as being a friend or moral advisor of the ruler, for example, through the topos of being in constant conversation with the emperor ${ }^{21}$.

Likewise, one of Adalbert of Prague's hagiographers claimed that during the Italian campaign, "the most Christian Caesar [Otto III], who always showed the greatest care and deepest solicitude towards the servant of God, often spoke to St. Adalbert and had him by his side as one of his closest, listening with pleasure to whatever he had to say"22. Later, during an encounter in Mainz: "The man of God remained with him for quite some time, because he was one of the closest. And he stayed day and night in the imperial bedchamber as the most holy attendant" 23 . In the chamber, Adalbert and Otto were engaged in "sweet conversations", and the saintly bishop taught Otto humility and "stimulated his desire for the heavenly homeland". Researches have established a direct borrowing of the idea and language of "holy conversations" from the homilies of Gregory the Great, whose treaties have already been mentioned as being extremely influential for episcopal self-fashioning and for understanding the role of the bishops ${ }^{24}$.

In his biography of Otto III, Gerd Althoff has stressed the idea of a royal "favour" to the bishop, quite often appearing in the vitae or gestae. In his words:

"There authors confirmed their protagonists' influence by describing them engaged in intensive and confidential conversation with the ruler. To provide only one example for comparison: the two known bishops' vitae from the time of Otto the Great - those of Ulrich of Augsburg and Bruno of Cologne - also describe and stress the bishops' influence with the ruler in the same way, by emphasizing that he discussed everything with them in intimate conversation" 25 .

This boasting of a fictitious connection with a ruler was created in texts by attributing the role of the king's friend, confessor or spiritual instructor to the bishop. The ideal of having direct access to the king and being treated as his friend appears to have been highly valued in the Ottonian realm. It influenced the common use of the topos of being in constant conversation with the king, which served to highlight the royal benevolence towards the protagonist. Hence, these reports should not be taken at a face-value: these roles as advisor or confessor were thrusted upon the image of the bishop in the literary works. The ideal of close connections between a king and a bishop was one of the "key components in the rhetoric of admonitio", and cited authors were operating in this framework ${ }^{26}$.

21 Gerd ALTHOFF, Otto III. University Park, PA 2003, pp. 137-139.

22 Life of Saint Adalbert Bishop of Prague and Martyr, trans. Cristian Gaşpar, in: Gábor Klaniczay (ed.), Saints of the Christianization Age of Central Europe (Tenth-Eleventh Centuries). Budapest 2013, pp. 156-157 (Christianissimus ille caesar, cui circa seruos Dei maximum studium semper et diligens cura fuit, crebro alloquitur sanctum Adalbertum et habebat eum sibi familiarem, audiens libenter, quaecumque sibi diceret). On veneration of St. Adalbert and specifically context of creation of this Life see the introduction to the English translation, also see: Sancti Adalberti Pragensis episcopi et martyris Vita prior, ed. Jadwiga KARWASIŃSKA (Monumenta Poloniae historica, Nova Series 4/1). Warszawa 1962; Johannes FRIED, Gnesen - Aachen - Rom: Otto III. und der Kult des hl. Adalbert: Beobachtungen zum älteren Adalbertsleben, in: Michael Borgolte (ed.), Polen und Deutschland vor 1000 Jahren: die Berliner Tagung über den "Akt von Gnesen". Berlin 2002, pp. 235-279.

23 Life of Saint Adalbert Bishop of Prague and Martyr (as above), pp. 158-159 (Cum quo vir Dei mansit bonum tempus, quia familiarissimus sibi erat; et nocte pariter ac die velut sanctissimus cubicularius imperiali camerae adfaesit).

${ }^{24}$ Life of Saint Adalbert Bishop of Prague and Martyr (as above), p. 159, footnote 6.

25 ALTHOFF, Otto III, p. 138.

26 WEILER (as above), p. 562. 
The creation of this specific image of close connection between a ruler and a bishop was highly important to the community, which a bishop represented and to whom his life and deeds were usually written about. This type of community can be defined as textual, or literary: a heterogeneous group of readers, authors and writers, bounded by a social practice of reading this text and a shared way of interpreting $i^{27}$. The favourable image of a main protagonist was used to establish the community's identity in cooperation with the imperial power, and, as in case of Worms, even to hint at an indebtedness of the royal office to the community. However, these intimate connections should seem persuasive to the audience of those texts. I assume that such credibility was based on the shared idealized role of the bishop, mostly rooted in the Patristic tradition. The notion of admonition and of episcopal preceptorship was propagated in the writings mostly of Gregory the Great and was emulated, at least in literary form or in the imagined past of a community.

\section{Bishop-prosecutor}

The episcopal duty of admonitio did not necessarily create a positive image of amicable relations between the bishop and the $\mathrm{king}^{28}$. A bishop could directly point at royal faults and request the monarch to repent for his sins, as happened when Louis the Pious was deposed and confronted with his crimes at Soissons in $833^{29}$. In the following scenarios, a bishop or a council of clerics played the role of a king's prosecutor, striving for the purity of the realm and its beholder. However, a bishop remained in the theological framework focused on admonition and on correcting people's sins, which was often presented by contemporary authors as an acceptable mode of exercising Kaiserkritik.

As Mayke de Jong has pointed out, a patristic concept of admonitio stands on the borderline with increpatio: within the latter framework, monition and council transition into "antagonistic recrimination" 30 . Increpatio is a concept from the Old Testament, and so is the prototype of a certain episcopal position towards a king: a prophet ${ }^{31}$. Bishops tend to adopt a role of the "watchman of the house of Israel", a paradigm explained in Ezekiel (esp. 3:16-27). This type of relationships between worldly and episcopal offices entered both practice and literary discourse in the ninth century Carolingian realm. The Ottonian Age is considered as a failure for episcopal recrimination and monition to be adopted and actively practiced ${ }^{32}$; however, I still see a possibility for transmission and transitions, rather than an abrupt change. In this part of the paper, I will draw attention to some

27 On the notion of textual communities see: Brian STOCK, Medieval Literacy, Linguistic Theory, and Social Organization, in: New Literary History, Vol. 16, No. 1, Oral and Written Traditions in the Middle Ages (Autumn, 1984), pp. 13-29; Anne CLARK BARTLETT, Miraculous Literacy and Textual Communities in Hildegard of Bingen's Scivias, in: Mystics Quarterly, Vol. 18, No. 2 (1992), pp. 43-55.

28 However, as Bjorn Weiler has highlighted, "admonition was not by definition anti-royal": WEILER (as above), p. 574.

29 On royal repentance in general and the events in Soissons see: Rudolf SCHIEFFER, Von Mailand nach Canossa: ein Beitrag zur Geschichte der christlichen Herrscherbuße von Theodosius dem Großen bis zu Heinrich IV., in: Deutsches Archiv für Erforschung des Mittelalters 28 (1972), pp. 333-370; JONG (as above), esp. pp. 214-259.

30 JONG (as above), p. 147.

31 JONG (as above), p. 115.

32 SUCHAN, Mahnen und Regieren, pp. 369-390. 
of the episodes from Ottonian authors, which presumably describe a similar paradigm of political practice, situated on the verge of admonitio and increpatio.

First, I will turn to a marginal narrative from the reign of Otto I, that is to be found only in the Deeds of the Bishops of Halberstadt ${ }^{33}$. A conflict between Otto I and Bishop Bernhard of Halberstadt escalated due to Otto's activities when establishing an archbishop in Magdeburg ${ }^{34}$. His wish to elevate Magdeburg to the status of archbishopric is linked to the triumphal victory over the Hungarians in the battle at Lechfeld in $955^{35}$. However, it took him more than ten tough years to eliminate opposition of clerics and other magnates who joint the resistance: only in 968 the foundation was approved on the Synod of Ravenna ${ }^{36}$. While Otto I eventually managed to silence the opposition, memories of this episcopal resistance against a royal wish lived on for much longer, mostly in local historiographic traditions.

According to the gesta episcoporum, in 966 Emperor Otto had to imprison Bishop Bernhard, who, in his turn, rebuked the emperor and excommunicated him. Similar to the scenario of the Carolingian "penitential state", Otto I had to make a public repentance to expiate his guilt:

"After the emperor went a little from the city, he, truly moved by divine inspiration, suddenly returned barefoot as a penitent, prostrated on the ground before the aforementioned bishop [Bernhard], and obtained the favour of absolution, which he humbly asked for"37.

As a result of the royal repentance, "the entire dispute between the emperor and the bishop finished" 38 . After the received absolution, Otto I entered Halberstadt as a triumphant lord and the conflict was never mentioned again in the lifetime of Bishop Bernhard: their relationships returned to the amicitia and auctoritas paradigm. The author of

33 On the genre of gesta episcoporum and abuse of this source see: Thomas F. HEAD, Postscript: the Ambiguous Bishop, in: The Bishop Reformed, pp. 250-264.

34 More about the conflict around Magdeburg and the role of Bishop Bernhard see: Helmut BEUMANN, Entschädigungen von Halberstadt und Mainz bei Gründung des Erzbistums Magdeburg, in: Festschrift für Harald Zimmermann, Sigmaringen 1991, pp. 383-398; Gerd ALTHOFF, Magdeburg - Halberstadt - Merseburg: Bischöfliche Repräsentation und Interessenvertretung im ottonischen Sachsen, in: Gerd Althoff - Ernst Schubert (eds.), Herrschaftsrepräsentation im ottonischen Sachsen. Sigmaringen 1998, pp. 268-275; Matthias BECHER, Otto der Grosse: Kaiser und Reich: eine Biographie. Munich 2012, pp. 235-237.

35 For more about the Lechfeld battle see: Lorenz WEINRICH, Tradition und Individualität in den Quellen zur Lechfeldschlacht 955, in: Deutsches Archiv für Erforschung des Mittelalters 27 (1971), pp. 291-313; Charles R. BOWLUS, The Battle of Lechfeld and Its Aftermath, August 955: the End of the Age of Migrations in the Latin West. Aldershot 2006.

36 Odilo ENGELS, Die Gründung der Kirchenprovinz Magdeburg und die Ravennater 'Synode' von 968, in: Annuarium Historiae Conciliorum 7 (1975), pp. 136-158.

37 Gesta episcoporum Halberstadensium, ed. Ludwig WEILAND, in: MGH Scriptores (in Folio). Bd. 23. Hannover 1874, pp. 83-84 (Imperator vero divina inspiratione conpunctus, a civitate aliquantulum retrogressus, penitentium more nudis pedibus subito regrediens, coram prefato episcopo humotenus est prostratus, et absolutionis beneficium, quod ab ipso humiliter peciit, impetravit).

38 Gesta episcoporum Halberstadensium (as above), pp. 83-84 (Sic igitur inter imperatorem et episcopum omnis controversia est finite). More on this event see: ALTHOFF, Magdeburg - Halberstadt - Merseburg, pp. 274-275. This example of royal penance was also mentioned in Gerd ALTHOFF, Die Macht der Rituale: Symbolik und Herrschaft im Mittelalter. Darmstadt 2003, pp. 110-111. However, Althoff views this act as humiliation before God and "heavenly powers" and an abstract plea for atonement, while the author of gesta clearly underlined the role of bishop in penance and following reconciliation and friendly relationship between Otto and Bernhard. 
the gesta episcoporum presented Bishop Bernhard as taking the role of the king's persecutor and the "watchman of the house", striving for the personal guiltlessness of the ruler and the purity of the kingdom. At the same time, the reproach and excommunication had also an overtone of a personal vindication.

This episode, which is described only in the local historiographic tradition of Halberstadt, raised a lot of doubts concerning its credibility and time of creation. The corpus of the Deeds of the Bishops of Halberstadt was compiled at the beginning of the thirteenth century and relies largely on earlier sources from the Ottonian age, such as Widukind's the Deeds of the Saxons and Thietmar's Chronicle. Kurt-Ulrich Jäschke has established that the layer of the text which narrates the discord between Otto I and Bernhard can be traced back to the end of the tenth century, between 992 and $996^{39}$. In this case, the gesta transmitted the events as preserved in the memory and oral communication of the next generation, the communicative memory ${ }^{40}$. Whether the communicative memory can be considered as a "reliable" source for "traditional" historical craft, namely reconstructing the course of event, is a debated question. However, a memory per se is of a great worth when analysing representational strategies of a community and, in this case, the role of a bishop as contributing to the self-identification of a group.

The image of Bishop Bernhard in the gesta, whether historically credible or not, is extremely powerful: first, Bernhard had the courage to excommunicate the emperor; later, he moved Otto I to repentance. Why was a bishop entrusted with such an authority, not only to admonish a ruler, but also to prosecute his sins? I would argue that in this local commemoration of the conflict between a bishop and a king a discussed biblical motive of increpatio was utilized as a narrative model.

The idea of the prosecutor-bishop is rooted in the Old Testament. The second book of Samuel and the first book of Chronicles contain episodes which drastically influenced the medieval understanding of worldly power and the representation of Christian kings. David, the powerful ruler of the kingdom of Israel, was moved to repentance twice by prophets, representatives of God's will on earth. First, by the Prophet Nathan after the king seduced Bathsheba and sent her husband Uriah to death ${ }^{41}$. The second time, David provoked God's wrath by taking census of the Israeli people, not believing that victory depended on the will of the Lord rather than the multitude of David's warriors. Therefore, the seer Gad was sent by the Lord to David to persuade the king to repent ${ }^{42}$. It took quite a while to develop a doctrine of episcopal power, giving clerics the right to admonish kings and to be their judges and moral arbiters. Ambrose, bishop of Milan, was the first to recognize and utilize the bishop's authority over a ruler. Ambrose used the image of David as an example for Emperor Theodosius, who was forced to publicly atone for his sin, namely the massacre at Thessaloniki in $390^{43}$.

39 Kurt-Ulrich JÄSCHKE, Die älteste Halberstädter Bischofschronik. Köln 1970.

40 Jan ASSMANN, Religion and Cultural Memory: Ten Studies. Stanford 2006.

412 Sam. 11-12.

42 1 Chron. 21-22.

43 Main works on Ambrose and Theodosius: Neil B. McLYNN, Ambrose of Milan: Church and Court in a Christian Capital. Berkeley 1994; John MOORHEAD, Ambrose: Church and Society in the Late Roman World. London/New York 1999; Hartmut LEPPIN, Theodosius der Grosse. Darmstadt 2003; Hartmut LEPPIN, Zum politischen Denken des Ambrosius: Das Kaisertum als pastorales Problem, in: Therese Fuhrer (ed.), Die christlich-philosophischen Diskurse der Spätantike. Stuttgart 2008, pp. 33-50; 
Since then, royal penance had become both an influential political ritual from the arsenal of royal ceremonies and an instrument of exercising episcopal power of admonitio and increpatio. Bishops also used their right of correction during the reign of Louis the Pious and twice forced the king to perform public penance, though with different outcomes ${ }^{44}$. This ritual of royal repentance points to a specific connection between the wellbeing of a kingdom and the moral behaviour of its ruler on the one hand, and between a king and the Church as his moral arbiter on the other ${ }^{45}$. Even though there is no clear evidence that Ottonian ecclesiastical discourse was knowledgeable of the royal admonition performed by their Carolingian forerunners, the authority of bishop Bernhard of Halberstadt indeed echoes the same principle of episcopal admonition. The bishop has a responsibility to redeem the sins of the ruler, influence his soul and behaviour, and bring the Empire back on the road to salvation.

A similar image of an ecclesiastical authority prosecuting the ruler for his sins can be illustrated by two rather famous examples, both staged during the Second Italian Campaign of Otto III ${ }^{46}$. The emperor, fiercely suppressing the revolt in Rome, mutilated Crescentius, the leader of the Roman aristocracy, and John Philagathos, the antipope ${ }^{47}$. The Lives of two contemporary Italian ascetics, Nilus the Younger and Romuald, recount that both saints pointed Emperor Otto's misdeeds out to him and moved him to repentance. Even though these two narratives belong to two different cultural and literary traditions (Italo-Greek monasticism and the Gregorian reform movement), they both utilize the patristic concept of admonition, as Sarah Hamilton has convincingly shown ${ }^{48}$. Along with this, both hagiographers aimed to evoke in their readers the notions of sacerdotal superiority and royal humility when invoking the David model, to which the Lives clearly allude $^{49}$. The commemoration strategy resembles the Halberstadt case: a religious com-

Patrick BOUCHERON - Stéphane GIOANNI (eds.), La mémoire d'Ambroise de Milan: usages politiques d'une autorité patristique en Italie (Ve-XVIII siècle). Paris/Roma 2015. In the last volume see especially an article by Miriam Rita Tessera. On the context of Ambrose's letter to Theodosius, its meaning and creation of a new ritual see: Michail A. BOJCOV, Raskajanie gosudarja: imperator i episkop [Repentance of a Prince: the Emperor and the Bishop], in: Vlast, Obshestvo i Individ v Srednevekovoy Evrope [Power, Society, and Individual in Medieval Europe]. Moskva 2008, pp. 211-242.

44 The recent publication on penances of Louis the Pious is: JONG (as above). On this pontifical with regard to penitential practices: Sarah HAMILTON, The Practice of Penance, 900-1050. Woodbridge/ Rochester 2001, pp. 25-50.

45 Monika Suchan claims that Louis the Pious monopolized the admonition practice for himself, while preciously this duty was carried out both by bishops and kings: SUCHAN, Mahnen und Regieren, esp. pp. 233-291.

46 With regard to the "Italienpolitik" see: Mathilde UHLIRZ, Kaiser Otto III. und das Papsttum, in: Historische Zeitschrift 162 (1940), pp. 258-268; Egon BOSHOF, Katastrophe oder Katalysator?: kaiserliche Italienpolitik von den Ottonen bis zu den Staufern, in: Ursula Triller (ed.), Europäische Begegnungen: die Faszination des Südens. München 2001, pp. 29-54; ALTHOFF, Otto III, pp. 72-89; Herbert ZIELINSKI, Der Weg nach Rom: Otto der Große und die Anfänge der ottonischen Italienpolitik, in: Wilfried Hartmann - Klaus Herbers (ed.), Die Faszination der Papstgeschichte: neue Zugänge zum frühen und hohen Mittelalter. Köln 2008, pp. 97-108; Uta-Renate BLUMENTHAL, The Investiture Controversy: Church and Monarchy from the Ninth to the Twelfth Century. Philadelphia 2010.

47 For more details about this revolt see: ALTHOFF, Otto III, pp. 72-90; Sarah HAMILTON, Otto III's Penance: A Case Study of Unity and Diversity in the Eleventh-Century Church, in: Studies in Church History 32 (1996), pp. 83-94.

48 HAMILTON, Otto III's Penance.

49 For example, Peter Damian, the author of the Life of St Romuald, accused Otto III of seducing the wife of mutilated Crescentius, which is similar to the sin of Kind David. The anonymous Greek author of 
munity established its identity against the royal power and confirmed its independence as well as, to a certain extent, superiority over the mundane authorities.

The famous letter of Bruno of Querfurt to King Henry II from c. 1008 serves as a perfect illustration of the episcopal duty to advice and admonish a ruler, and to correct his sins ${ }^{50}$. This letter has been heartily discussed in respect to King Henry's politics in the East of the realm, namely his temporary union with the pagan Liutizi against Bolesław I Chrobry ${ }^{51}$. However, I would leave these questions aside and briefly pay attention to the rhetoric of the letter which Bishop Bruno utilized to express his Kaiserkritik in a most subtle way.

At the beginning of the letter, after rather conventional praises for King Henry, Bruno of Querfurt imputes on him such sinful emotions as "fear, anger, and mockery", which Henry had expressed in relation to Bruno's missionary activities among the Slavic peoples $^{52}$. Later, Bishop Bruno straightforwardly rebukes Henry: "But, if it is permitted to speak thus without losing the king's grace: Is it good to persecute a Christian people and hold a pagan people in friendship? ... On what battle line do the sacred lance and the diabolic banners, which are nourished with human blood, go forth together?"53 And then: "After the holy emperor Constantine the Great, after Charles, that best exemplar of religion, there is now someone who persecutes the Christian, but almost no one who converts the pagan". This indictment reveals a sin which King Henry committed, and therefore would have to repent if not wishing to leave the fate of the whole empire in danger. And Bishop Bruno imagined himself as the right person to admonish the sinned ruler: it was a part of his pastoral duties.

This model of relations between the bishop and the ruler also implied that secular power should be judged by the Church, whereby popes, bishops and saints can rightfully claim the highest moral authority. This motive was often invoked in local traditions in order to maintain the identities of the local communities and separate them from royal influence. This "bishop-persecutor" model goes beyond a literary convention: it rests on biblical and patristic traditions, followed by historical precedents which altogether shaped the politics and behaviour of the bishops, as revealed by the example of Bruno of Querfurt. With an exception of the Decretum of Burchard of Worms, Ottonian liter-

the Life of St Nilus referred several times to the penitential psalms, attributed to David. For more, see: HAMILTON, Otto III's Penance.

50 For the contextualization and analysis of the letter see recent articles: WARNER, Saints, Pagans, War and Rulership in Ottonian Germany; Wojciech FAŁKOWSKI, The Letter of Bruno of Querfurt to King Henry II, in: Frühmittelalterliche Studien 43 (2009), pp. 417-438; WEILER (as above).

51 For a more detailed historical context see corresponding chapters in: Stefan WEINFURTER, Heinrich II., 1002-1024: Herrscher am Ende der Zeiten. Regensburg 2000.

52 On the one hand, these characteristics of Henry II can be understood as having sinful origin, as far as emotions could have been viewed as a category of sins, and thus they work as a harsh criticism of a ruler. On the other hand, Fałkowski interpreted "fear, anger and mockery" as signs of interest expressed by the ruler to Bruno: FAŁKOWSKI (as above), pp. 427-428. Gerd Althoff has briefly traced the idea of ira regis and its various interpretations: from a requirement for a successful royal conduct to "a proof that a ruler could not meet the demands of his office": Gerd ALTHOFF, Ira Regis: Prolegomena to a History of Royal Anger, in: Barbara H. Rosenwein (ed.), Angers Past: the Social Uses of an Emotion in the Middle Ages. Ithaca/London 1998, pp. 59-74.

53 The Letter of Bruno of Querfurt to King Henry II., trans. by W. L. North from the edition and notes of Jadwiga KARWASINSSKA, Epistola ad Henricum regem (Monumenta Poloniae historica, Nova Series 4/3). Warszawa 1973, pp. 97-106: https://apps.carleton.edu/curricular/mars/assets/Bruno_of_Querfurt_Letter_to_Henry_II_for_MARS_website.pdf 
ary and scholarly environment did not produce extensive treaties devoted to a theory of episcopal (or in general, clerical) power. However, the steady process of crystallization of these ideas did take place in the Ottonian intellectual circles, as one can trace through typified images of bishops.

\section{Bishop-traitor and rebellious bishops}

The final concept that is tackled in this paper is that of a bishop represented being in an open disagreement with a mundane ruler. In narratives of the period, this relationship between episcopal and royal powers was depicted from two different angles. On the one hand, by contradicting royal will, a bishop could have exercised his "right of rebellion", hence his actions were in conformity with the Spielregeln of the political climate. On the other hand, an episcopal disagreement could have been understood as an act of betrayal and negligence of his own episcopal duties.

A right of disagreement was a crucial concept of social and political environment of the Early Medieval political formations. Relations between territorial lords and a ruler were regulated by unwritten sets of rules, expressed by ritualized actions; as profoundly discussed by Karl Leyser and Gerd Althoff, an opportunity to disagree and to rebel were one of these ritualized political means to negotiate the power ${ }^{54}$. Equally important was to facilitate the establishment of the order after breakouts of disagreement: a social institute of "begging pardon and favour" evoked ${ }^{55}$. In the tenth-eleventh centuries, bishops functioned also as powerful territorial lords and political leaders (examples of Ulrich of Augsburg or Bruno of Cologne are more than excessive). Consequently, the twofold mechanism of disagreement and pardon should have also shaped the relations between rulers and bishops. Together with previously discussed concepts of admonition and pastoral care, these gave Ottonian authors a framework of either condemning or justifying ecclesiastical lords. First, I recount briefly several examples of bishops who were convicted of betraying a ruling king (hence, deprived of their opportunity to rebel); the second part is devoted to the cases, in which an episcopal right of rebellion was approved.

When it comes to descriptions of bishops, who conspired against or betrayed a ruler, there is a striking similarity in the way Ottonian authors described and devalued these acts. "Non pastor, sed lupus" is how the author of the Quedlinburg Annals damned John Philagathos, a clergyman of Greek origin, who became an antipope during the revolt in Rome in 997 as has already been mentioned before. Unlike the Lives of the Italian saints Nilus and Romuald, which depicted the mutilated rebels in a favourable light and put all the blame on Otto III, the Quedlinburg annalist condemned the conspirators and proclaimed the coup to be a rebellion against the emperor and the Church ${ }^{56}$.

\footnotetext{
54 Karl LEYSER, Rule and Conflict in an Early Medieval Society: Ottonian Saxony. London 1979; Gerd ALTHOFF, Das Privileg der deditio: Formen gütlicher Konfliktbeendigung in der mittelalterlichen Adelsgesellschaft, in: Gerd Althoff (ed.), Spielregeln der Politik im Mittelalter. Darmstadt 1996, pp. 99-125.

55 KOZIOL (as above).

56 Die Annales Quedlinburgenses, ed. Martina GIESE (MGH Scriptores rerum Germanicarum in usum scholarum separatim editi. Bd. 72). Hanover 2004, pp. 495-497.
} 
In his Chronicle, Thietmar of Merseburg, a bishop himself, described his malignant enemy Gisilher (at that time, the bishop of Merseburg) as "non pastor, sed mercenarius" 57. Thietmar accused Gisilher of obtaining the see of Magdeburg cunningly, through deceit and by taking advantage of Otto II's benevolence ${ }^{58}$. Initially, Gisilher was meant to intercede for the Magdeburg community in front of Otto II and promote their own candidate; however, he deceived both the see of Magdeburg and the king: Gisilher betrayed royal favour and asked the see for himself, which led to the distortion of the bishopric in Merseburg ${ }^{59}$. However, one has to acknowledge that personal enmity between Thietmar of Merseburg, the author of this text, and Gisilher of Magdeburg shaped a negative image of Gisilher and added dramatic overtones in this specific passage. As far as Thietmar perceived the prosperity of the kingdom being strongly connected to his diocese of Merseburg, the dissolution of the latter put a shade over the whole kingdom ${ }^{60}$. Gisilher, who, according to his pastoral duties, had to take care of the salvation of the empire, did quite the opposite, from Thietmar's standpoint; hence, he failed to be a true pastor to his flock.

Similarly expressed accusations of episcopal infidelity can also be found in the epistolary genre, namely in the letters of Gerbert d'Aurillac, the future Pope Sylvester II. "Quasi vero tu pastor, et non lupus rapax, et potius alter Judas", that is how Gerbert referred to his addressee, Bishop Deitrich of Metz, on behalf of Charles of Lower Lotharingia. Dietrich was accused of betraying the young king Otto III, despite of his close connections to the royal family, in favour of Henry of Bavaria; although Duke Charles would later excuse himself for the sharp accusations ${ }^{61}$.

In these three examples, the authors, among whom two are bishops themselves, accuse the bishops of betraying the ruler or the interests of the realm, and they refuse to call them worthy bishops, pastor verus. This close connection between exercising pastoral duties and being loyal to the ruler is expressed in the formula "non pastor sed lupus", though the second element of the negation can also refer to a hireling or Judas. The wording is an echo of the verses from Christ's preaching before the Jews, narrated in the Gospel of John (10:11-14), ${ }^{62}$ and the mount sermon from the Gospel of Matthew (7:15): "Beware of false prophets, who come to you in the clothing of sheep, but inwardly they are ravening wolves"63.

57 Thietmari Merseburgensis episcopi Chronicon, ed. Robert HOLTZMANN (MGH Scriptores rerum Germanicarum. Nova series. Bd. 9). Berlin 1935, pp. 112-113 (III 13-14).

58 More on the conflict see: Robert HOLTZMANN, Die Aufhebung und Wiederherstellung des Bistums Merseburg, in: Sachsen und Anhalt 2 (1926), pp. 35-75; ALTHOFF, Magdeburg - Halberstadt Merseburg: bischöfliche Repräsentation und Interessenvertretung im ottonischen Sachsen.

59 On the role of episcopal intercession see: GILSDORF (as above), pp. 125-152.

60 Helmut LIPPELT, Thietmar von Merseburg: Reichsbischof und Chronist. Köln 1973; Kerstin SCHULMEYER-AHL, Der Anfang vom Ende der Ottonen: Konstitutionsbedingungen historiographischer Nachrichten in der Chronik Thietmars von Merseburg. Berlin 2009.

61 A Letter from Charles, Duke of Lower Lotharingia, to Bishop Dietrich of Metz (May/June 984), in: Fritz Weigle (ed.), Die Briefsammlung Gerberts von Reims (MGH Epistolae. Die Briefe der deutschen Kaiserzeit. Bd. 2). Weimar 1966, p. 58 (nr. 32). On Bishop Dietrich and the political circumstances behind this letter see: Dominik WASSENHOVEN, Swaying Bishops and the Succession of Kings, in: Ludger Körntgen - Dominik Wassenhoven (eds.), Patterns of Episcopal Power: Bishops in Tenth and Eleventh Century Western Europe. Berlin 2011, pp. 94-96.

62 "I am the good shepherd. The good shepherd giveth his life for his sheep. But the hireling and he that is not the shepherd, whose own the sheep are not, sees the wolf coming and leaves the sheep and flies".

${ }^{63}$ On the origins of "pastoral power" and the use of this metaphor see: SUCHAN, Mahnen und Regieren. 
In these excerpts, a distinction is made between the natures of true and false spiritual leaders, where the main virtue is to take care of the flock. Even though one cannot find any remarks about the relations between ecclesiastical and worldly powers in these verses, these exact famous excerpts were chosen by Ottonian authors as rhetorical forms to describe not just unworthy bishops, but those, who betrayed the ruler. I would suggest that maintaining the role of the bishop was tightly bound with being loyal to a king within Ottonian indigenous political theology.

The other literary representation, that of a "rebellious bishop", was comprehensively discussed by Ernst-Dieter Hehl ${ }^{64}$. While the image of a betrayer was thrusted upon bishops such as Giselher, John Philagathos or Dietrich, similar disagreements between ruler and bishop were explained as an expression of the episcopal right to discord, briefly analysed above. Fashioning episcopal disagreement with mundane authorities as realization of this right, often conducted in a ritualized form, allowed a bishop to keep his honour and clerical status even when disagreeing with a king.

An example of such rebellious bishops can be found in a famous episode from the Chronicle of Thietmar of Merseburg: namely, the Frankfurt synod in $1007^{65}$. A decision by King Henry II to establish a diocese in Bamberg faced severe discontent from the bishops. During the synod, King Henry plead bishops to grant him a right to establish a diocese, and, according to Thietmar, the king continuously repented and kneeled in front of the bishops until they gave him their consent. This puzzling scene has undergone innumerable interpretations from different theoretical frameworks, such as ritual studies, memory creation, new constitutional history etc. ${ }^{66}$ Most of the researchers concentrated on questions of credibility of this narrative and possible prototype for such a seemingly unusual gesture of a king, and Gerd Althoff was among the first ones who hinted to the possible ironic use of such narrations ${ }^{67}$. Ernst-Dieter Hehl, in his turn, analysed episcopal behaviour, especially in times of succession crisis, as a realization of their right to rebel and express their agency. The only way for the king to overcome "stubbornness" of the presiding bishops was a ritual humiliation in front of the synod. In the end, his repentance and royal plea were utilized as a symbolic argument in the dispute concerning Bamberg.

This narration, on the one hand, questions the leading role of a king in the Imperial Church, and, on the other hand, shows how fragile "discordant" bishops were in the hands of the authors who depicted them. Depending on the position of the chronicler and the inner logic of the text, episcopal discord with the ruler was tolerated in some cases, while it was condemned as treason in the others.

64 Ernst-Dieter HEHL, Der widerspenstige Bischof: bischöfliche Zustimmung und bischöflicher Protest in der ottonischen Reichskirche, in: Herrschaftsrepräsentation im ottonischen Sachsen, pp. 295-344.

65 Thietmari Chronicon (as above), pp. 310-313 (VI 30-32).

66 David A. WARNER, Thietmar of Merseburg on Rituals of Kingship, in: Viator 26 (1995), pp. 53-76; Stefan WEINFURTER, Authority and Legitimation of Royal Policy and Action: the Case of Henry II, in: Gerd Althoff - Johannes Fried - Patrick Joseph Geary (eds.), Medieval Concepts of the Past: Ritual, Memory, Historiography. Cambridge 2002, pp. 19-37.

67 ALTHOFF, Die Macht der Rituale, pp. 121-123. 


\section{Conclusion}

In the Ottonian historiography, bishops are presented as confessors for kings, as the kings' closest advisors, or, quite on the contrary, as royal prosecutors or traitors of the realm. However, all these images are realizations of the same political principles and theological notions which constitute the office of a bishop, on which, consequently, the relations between episcopal and royal power were built in the Ottonian realm: admonitio, correptio, familiaritas, being a true pastor and a loyal territorial lord at the same time.

Even though the principle of admonition was not exercised as often as in the Merovingian or Late Carolingian epochs, it was an extremely important component in constructing and understanding the relations between the ruler and the bishop. The notion of an episcopal duty to take care of the flock and the realm made it possible to imagine a bishop being an advisor and spiritual director of the king. Furthermore, it provided bishops with the authority to admonish the ruler and express their discord. The depiction of a bishop as a close friend of the ruler was bound to the value of "closeness", both during public ceremonies and in private encounters. Not only access to the king mattered, but also loyalty to the ruler: this idea of faithfulness was bound to an image of the bishop as a true pastor and a territorial prince of the kingdom.

Most of these notions were not invented in the Ottonian intellectual sphere and were based on reconsideration of biblical prototypes and patristic tradition, corrected according to the political and social environment of the age. However, these exact traditions, together with the interpretative tools and personal aims of Ottonian historiographers and their audiences, made it possible to thrust the discussed images of saints, traitors, advisors or prosecutors upon bishops and kings. Indeed, the Ottonian epoch was an age of charismatic bishops, whose intricate relations with the Ottonian ruler and ambivalent position in the church system define our contemporary perception of the medieval power structures $^{68}$.

\section{REFERENCES}

\section{Sources}

Die Annales Quedlinburgenses, ed. Martina GIESE (MGH Scriptores rerum Germanicarum in usum scholarum separatim editi. Bd. 72). Hannover 2004.

Gesta episcoporum Halberstadensium, ed. Ludwig WEILAND, in: MGH Scriptores (in Folio). Bd. 23. Hannover 1874, pp. 73-123.

GREGORY the Great, The Book of Pastoral Rule. Crestwood/New York 2007.

A Letter from Charles, Duke of Lower Lotharingia, to Bishop Dietrich of Metz (May/June 984), in: Fritz Weigle (ed.), Die Briefsammlung Gerberts von Reims (MGH Epistolae. Die Briefe der deutschen Kaiserzeit. Bd. 2). Weimar 1966, p. 58 (Nr. 32).

The Letter of Bruno of Querfurt to King Henry II., trans. by W.L. North from the edition and notes of Jadwiga KARWASINSSKA, Epistola ad Henricum regem (Monumenta Poloniae historica, Nova Series 4/3). Warszawa 1973, pp. 97-106: https://apps.carleton.edu/curricular/mars/assets/Bruno_of_Querfurt_Letter_to_Henry_II_for_MARS_website.pdf.

68 REUTER, Ein Europa der Bischöfe. 
Life of Saint Adalbert Bishop of Prague and Martyr, trans. Cristian Gaşpar, in: Gábor Klaniczay (ed.), Saints of the Christianization Age of Central Europe (Tenth-Eleventh Centuries). Budapest 2013, pp. 96-181.

Sancti Adalberti Pragensis episcopi et martyris Vita prior, ed. Jadwiga KARWASIŃSKA (Monumenta Poloniae historica, Nova Series 4/1). Warszawa 1962.

Thietmari Merseburgensis episcopi Chronicon, ed. Robert HOLTZMANN (MGH Scriptores rerum Germanicarum. Nova series. Bd. 9). Berlin 1935.

Vita Burchardi episcopi, ed. Georg WAITZ, in: MGH Scriptores (in Folio). Bd. 4. Hannover 1841. (The Life of Bishop Burchard of Worms, trans. W. L. North, in: Medieval Sourcebook, https://legacy.fordham .edu /Halsall /source /1025burchard-vita.asp)

\section{Bibliography}

Gerd ALTHOFF, Ira Regis: Prolegomena to a History of Royal Anger, in: Barbara H. Rosenwein (ed.), Angers Past: The Social Uses of an Emotion in the Middle Ages. Ithaca/London 1998, pp. 59-74.

Gerd ALTHOFF, Die Macht der Rituale: Symbolik und Herrschaft im Mittelalter. Darmstadt 2003.

Gerd ALTHOFF, Magdeburg - Halberstadt - Merseburg: bischöfliche Repräsentation und Interessenvertretung im ottonischen Sachsen, in: Gerd Althoff - Ernst Schubert (eds.), Herrschaftsrepräsentation im ottonischen Sachsen. Sigmaringen 1998, pp. 268-275.

Gerd ALTHOFF, Otto III. University Park, PA 2003.

Gerd ALTHOFF, Das Privileg der deditio: Formen gütlicher Konfliktbeendigung in der mittelalterlichen Adelsgesellschaft, in: Gerd Althoff (ed.), Spielregeln der Politik im Mittelalter. Darmstadt 1996, pp. 99-125.

Gerd ALTHOFF, Spielregeln der Politik im Mittelalter: Kommunikation in Frieden und Fehde. Darmstadt 1997.

Gerd ALTHOFF, Verwandte, Freunde und Getreue: zum politischen Stellenwert der Gruppenbindungen im fruhen Mittelalter. Darmstadt 1990.

Gerd ALTHOFF, Was verstehen Mittelalter-Historiker eigentlich unter einer Fiktion?, in: Merle Marie Schütte - Kristine Rzehak - Daniel Lizius (eds.), Zwischen Fakten und Fiktionen: Literatur und Geschichtsschreibung in der Vormoderne. Würzburg 2014, pp. 155-168.

Jan ASSMANN, Religion and Cultural Memory: Ten Studies. Stanford 2006.

Matthias BECHER, Otto der Grosse: Kaiser und Reich: eine Biographie. München 2012.

Walter BERSCHIN, Biographie und Epochenstil im lateinischen Mittelalter: ottonische Biographie, das hohe Mittelalter 920-1220, vol. 4. Stuttgart 1999.

Helmut BEUMANN, Entschädigungen von Halberstadt und Mainz bei Gründung des Erzbistums Magdeburg, in: Klaus Herbers - Hans-Henning Kortüm - Carlo Servatius (Hgg.), Ex Ipsis Rerum Documentis: Beträge zur Mediävistik: Festschrift für Harald Zimmermann zum 65. Geburtstag. Sigmaringen 1991, pp. 383-398.

Uta-Renate BLUMENTHAL, The Investiture Controversy: Church and Monarchy from the Ninth to the Twelfth Century. Philadelphia 2010.

Michael BORGOLTE, Biographie ohne Subjekt, oder wie man durch quellenfixierte Arbeit Opfer des Zeitgeistes werden kann, in: Gottingische Gelehrte Anzeigen 249 (1997), pp. 128-141.

Philippe BUC, Noch einmal 918-919: Of the Ritualized Demise of Kings and of Political Rituals in General, in: Gerd Althoff (ed.), Zeichen - Rituale - Werte: internationales Kolloquium Des Sonderforschungsbereichs 496 an Der Wesfalischen Wilhelms-Universitat Munster. Münster 2004, pp. 151-178.

Anne CLARK BARTLETT, Miraculous Literacy and Textual Communities in Hildegard of Bingen's Scivias, in: Mystics Quarterly 18, No. 2 (1992), pp. 43-55.

Michail A. BOJCOV, Raskajanie gosudarja: Imperator i episkop, in: Vlast, Obshestvo i Individ v Srednevekovoy Evrope. Moskva 2008, pp. 211-242.

Egon BOSHOF, Katastrophe oder Katalysator?: kaiserliche Italienpolitik von den Ottonen bis zu den Staufern, in: Ursula Triller (ed.), Europäische Begegnungen: die Faszination des Südens. München 2001, pp. 29-54.

Patrick BOUCHERON - Stéphane GIOANNI (eds.), La memoire d'Ambroise de Milan: usages politiques d'une autorite patristique en Italie ( $V^{e}-X V I I I^{e}$ siecle). Paris/Roma 2015. Charles R. BOWLUS, the Battle 
of Lechfeld and Its Aftermath, August 955: the End of the Age of Migrations in the Latin West. Aldershot 2006.

Patrick CORBET, Les saints ottoniens: saintete dynastique, royale et feminine autour de l'an Mil. Sigmaringen 1986.

Peter DINZELBACHER, Warum weint der Konig?: eine Kritik des mediavistischen Panritualismus. Badenweiler 2009.

Odilo ENGELS, Die Gründung der Kirchenprovinz Magdeburg und die Ravennater 'Synode' von 968, in: Annuarium Historiae Conciliorum 7 (1975), pp. 136-158.

Wojciech FAŁKOWSKI, The Letter of Bruno of Querfurt to King Henry II, in: Frühmittelalterliche Studien 43 (2009), pp. 417-438.

Albrecht Graf FINCK von FINCKENSTEIN, Bischof und Reich: Untersuchungen zum Integrationsprozess des ottonisch-fruhsalischen Reiches (919-1056). Sigmaringen 1990.

Johannes FRIED, Gnesen - Aachen - Rom: Otto III. und der Kult des hl. Adalbert: Beobachtungen zum älteren Adalbertsleben, in: Michael Borgolte (ed.), Polen und Deutschland vor 1000 Jahren: die Berliner Tagung uber den 'Akt von Gnesen'. Berlin 2002, pp. 235-279.

Martina GIESE, Die Historiographie im Umfeld des ottonischen Hofes, in: Rudolf Schieffer - Jarosław Wenta - Martina Giese (eds.), Die Hofgeschichtsschreibung im mittelalterlichen Europa: Projekte und Forschungsprobleme. Toruń 2006, pp. 19-37.

Sean J. GILSDORF, The Favor of Friends: Intercession and Aristocratic Politics in Carolingian and Ottonian Europe. Leiden 2014.

Hans-Werner GOETZ, Geschichtsschreibung und Geschichtsbewusstsein im hohen Mittelalter. Berlin 1999.

Michael GOODICH, Vita Perfecta, the Ideal of Sainthood in the Thirteenth Century. Stuttgart 1982.

Stephanie HAARLÄNDER, Vitae episcoporum: eine Quellengattung zwischen Hagiographie und Historiographie, untersucht an Lebensbeschreibungen von Bischofen des Regnum Teutonicum im Zeitalter der Ottonen und Salier. Stuttgart 2000.

Sarah HAMILTON, Otto III's Penance: a Case Study of Unity and Diversity in the Eleventh-Century Church, in: Studies in Church History 32 (1996), pp. 83-94.

Sarah HAMILTON, The Practice of Penance, 900-1050. Woodbridge/Rochester 2001.

Andreas HAMMER, Interferences Between Hagiography and Historiography: Bishop Ulrich of Augsburg and Emperor Henry II, in: Amsterdamer Beitrage Zur Alteren Germanistik 70 (2013), pp. 179-194.

Wilfried HARTMANN, Bischof Burchard von Worms: 1000-1025. Mainz 2000.

Thomas F. HEAD, Postscript: the Ambiguous Bishop, in: The Bishop Reformed: Studies of Episcopal Power and Culture in the Central Middle Ages. Aldershot 2007, pp. 250-264.

Ernst-Dieter HEHL, Der widerspenstige Bischof: bischöfliche Zustimmung und bischöflicher Protest in der ottonischen Reichskirche, in: Herrschaftsreprasentation im ottonischen Sachsen, pp. 295-344.

Robert HOLTZMANN, Die Aufhebung und Wiederherstellung des Bistums Merseburg, in: Sachsen und Anhalt 2 (1926), pp. 35-75.

Kurt-Ulrich JÄSCHKE, Die alteste Halberstadter Bischofschronik. Köln 1970.

Mayke de JONG, The Penitential State: Authority and Atonement in the Age of Louis the Pious, 814-840. Cambridge/New York 2009.

Geoffrey KOZIOL, Begging Pardon and Favor: Ritual and Political Order in Early Medieval France. Ithaca/ London 1992.

Hartmut LEPPIN, Theodosius der Grosse. Darmstadt 2003.

Hartmut LEPPIN, Zum politischen Denken des Ambrosius: das Kaisertum als pastorales Problem, in: Therese Fuhrer (ed.), Die christlich-philosophischen Diskurse der Spatantike. Stuttgart 2008, pp. 33-50.

Karl LEYSER, Rule and Conflict in an Early Medieval Society: Ottonian Saxony. London 1979.

Helmut LIPPELT, Thietmar von Merseburg: Reichsbischof und Chronist. Köln 1973.

Neil B. McLYNN, Ambrose of Milan: Church and Court in a Christian Capital. Berkeley 1994.

John MOORHEAD, Ambrose: Church and Society in the Late Roman World. London/New York 1999.

John Stephens OTT - Anna TRUMBORE JONES, Introduction: the Bishop Reformed, in: The Bishop Reformed: Studies of Episcopal Power and Culture in the Central Middle Ages. Aldershot 2007, pp. 1-20.

Eric PALAZZO, Leveque et son image: l'illustration du pontifical au Moyen Age. Turnhout 2000.

Timothy REUTER, Ein Europa der Bischöfe: das Zeitalter Burchards von Worms, in: Wilfried Hartmann (ed.), Bischof Burchard von Worms: 1000-1025. Mainz 2000, pp. 1-28. 
Timothy REUTER, The 'imperial Church System' of the Ottonian and Salian Rulers: a Reconsideration, in: The Journal of Ecclesiastical History 33 (1982), pp. 347-374.

Rudolf SCHIEFFER, Von Mailand nach Canossa: ein Beitrag zur Geschichte der christlichen Herrscherbuße von Theodosius dem Großen bis zu Heinrich IV., in: Deutsches Archiv für Erforschung des Mittelalters 28 (1972), pp. 333-370.

Kerstin SCHULMEYER-AHL, Der Anfang vom Ende der Ottonen: Konstitutionsbedingungen historiographischer Nachrichten in der Chronik Thietmars von Merseburg. Berlin 2009.

Gabrielle M. SPIEGEL, The Past as Text: the Theory and Practice of Medieval Historiography. Baltimore 1997.

Brian STOCK, Medieval Literacy, Linguistic Theory, and Social Organization, in: New Literary History, Vol. 16, No. 1, Oral and Written Traditions in the Middle Ages (Autumn, 1984), pp. 13-29.

Monika SUCHAN, Mahnen und Regieren: die Metapher des Hirten im früheren Mittelalter. Berlin 2015.

Monika SUCHAN, Monition and Advice as Elements of Politics, in: Ludger Körntgen - Dominik Wassenhoven (ed.), Patterns of Episcopal Power: Bishops in Tenth and Eleventh Century Western Europe. Berlin 2011, pp. 39-50.

Mathilde UHLIRZ, Kaiser Otto III. und das Papsttum, in: Historische Zeitschrift 162 (1940), pp. 258-268.

Andre VAUCHEZ, Sainthood in the Later Middle Ages. Cambridge 1997.

Hanna VOLLRATH, Haben Rituale Macht?: Anmerkungen zu dem Buch von Gerd Althoff: 'Die Macht der Rituale, Symbolik und Herrschaft im Mittelalter', in: Historische Zeitschrift 284 (2007), pp. 385-400.

David A. WARNER, Saints, Pagans, War and Rulership in Ottonian Germany, in: Robert C. Figueira (ed.), Plentitude of Power: the Doctrines and Exercise of Authority in the Middle Ages: Essays in Memory of Robert Louis Benson. Aldershot 2006, pp. 11-35.

David A. WARNER, Thietmar of Merseburg on Rituals of Kingship, in: Viator 26 (1995), pp. 53-76.

Dominik WASSENHOVEN, Swaying Bishops and the Succession of Kings, in: Ludger Körntgen Dominik Wassenhoven (eds.), Patterns of Episcopal Power: Bishops in Tenth and Eleventh Century Western Europe. Berlin 2011, pp. 94-96.

Björn WEILER, Clerical Admonitio, Letters of Advice to Kings and Episcopal Self-Fashioning, c. 1000 c. 1200, in: History 102, no. 352 (2017), pp. 557-575.

Stefan WEINFURTER, Authority and Legitimation of Royal Policy and Action: the Case of Henry II, in: Gerd Althoff - Johannes Fried - Patrick Joseph Geary (eds.), Medieval Concepts of the Past: Ritual, Memory, Historiography. Cambridge 2002, pp. 19-37.

Stefan WEINFURTER, Heinrich II., 1002-1024: Herrscher am Ende der Zeiten. Regensburg 2000.

Lorenz WEINRICH, Tradition und Individualität in den Quellen zur Lechfeldschlacht 955, in: Deutsches Archiv für Erforschung des Mittelalters 27 (1971), pp. 291-313.

Thomas WÜNSCH, Der heilige Bischof - Zur politischen Dimension von Heiligkeit im Mittelalter und ihrem Wandel, in: Archiv für Kulturgeschichte 82 (2000), pp. 261-302.

Herbert ZIELINSKI, Der Reichsepiskopat in spatottonischer und salischer Zeit, 1002-1125. Wiesbaden 1984.

Herbert ZIELINSKI, Der Weg nach Rom: Otto der Große und die Anfänge der ottonischen Italienpolitik, in: Wilfried Hartmann - Klaus Herbers (ed.), Die Faszination der Papstgeschichte: neue Zugänge zum frühen und hohen Mittelalter. Köln 2008, pp. 97-108. 